\title{
Thrips species (Insecta, Thysanoptera) inhabiting plants of the Parque Estadual de Itapuã, Viamão, Rio Grande do Sul state, Brazil ${ }^{1}$
}

\author{
Adriano Cavalleri ${ }^{2}$; Helena Piccoli Romanowski ${ }^{2}$ \& Luiza Rodrigues Redaelli ${ }^{2,3}$ \\ ${ }^{1}$ Contribution number 466 of the Departamento de Zoologia, Instituto de Biociências, Universidade Federal do Rio Grande \\ do Sul. \\ 2 Programa de Pós-Graduação em Biologia Animal, Departamento de Zoologia, Instituto de Biociências, Universidade Federal \\ do Rio Grande do Sul. Avenida Bento Gonçalves 9500, prédio 43435, 91501-970 Porto Alegre, Rio Grande do Sul, Brasil. \\ E-mail: cavalleri_adriano@yahoo.com.br \\ ${ }^{3}$ Departamento de Fitossanidade, Faculdade de Agronomia, Universidade Federal do Rio Grande do Sul. Avenida Bento \\ Gonçalves 7712, 91540-000 Porto Alegre, Rio Grande do Sul, Brasil.
}

\begin{abstract}
This study is a contribution to the knowledge of the thysanopterofauna of southern Brazil. From June 2003 to April 2004, seasonal field trips were conducted at the Parque Estadual de Itapuã $\left(50^{\circ} 50^{\prime}-51^{\circ} 05^{\prime} \mathrm{W}\right.$ and $\left.30^{\circ} 20^{\prime}-30^{\circ} 27^{\prime} \mathrm{S}\right)$, in the county of Viamão, Rio Grande do Sul, to collect shoots with/without flowers of various plant species. The material was brought to the laboratory where the thrips were sorted. A total of 23 thrips species belonging to 15 genera and two families were obtained. Nine of the species resulted as new record for Rio Grande do Sul $\left({ }^{\star}\right)$, and other two also for Brazil $\left({ }^{\star}\right)$. The species sampled are as follows: Aneristothrips claripennis (Moulton, 1933) ${ }^{\star}$, Aurantothrips orchidearum (Bondar, 1931) ${ }^{\star}$, Ceratothripoides lagoenacollus (Moulton, 1933) ${ }^{\star}$, Chaetanaphothrips orchidii (Moulton, 1907) ${ }^{\star}$, Chaetisothrips striatus (Hood, 1935), Coremothrips pallidus Hood, 1925 , Craniothrips urichi Bagnall, 1915, Frankliniella bertelsi (De Santis, 1967), Frankliniella distinguenda Bagnall ${ }^{\star}, 1919$, Frankliniella gardeniae Moulton, 1948 , Frankliniella gemina Bagnall, 1919, Frankliniella insularis (Franklin, 1908), Frankliniella oxyura Bagnall, 1919*, Frankliniella rodeos Moulton, 1933, Haplothrips fiebrigi Priesner, 1931, Hoodothrips lineatus (Hood, 1928), Microcephalothrips abdominalis (Crawford, 1910), Neohydatothrips denigratus (De Santis, 1966) , Neohydatothrips fasciatus (Moulton, 1938) ${ }^{\star}$, Neohydatothrips flavens (Moulton, 1941), Paraleucothrips minusculus Johansen, 1983 Smicrothrips particula Hood, 1952, Thrips australis (Bagnall, 1915).

KEY WORDS. Conservation unit; faunal record; Neotropical thysanopterofauna.
\end{abstract}

RESUMO. Espécies de tripes (Insecta, Thysanoptera) habitantes da vegetação do Parque Estadual de Itapuã, Viamão, Rio Grande do Sul, Brasil. O presente estudo visa contribuir para o conhecimento da tisanopterofauna do sul do Brasil. Entre junho de 2003 e abril de 2004, foram realizadas saídas de campo para o Parque Estadual de

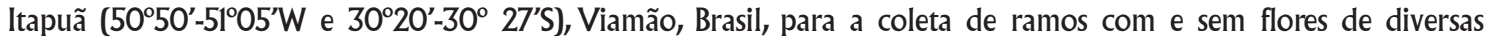
espécies vegetais. $O$ material foi levado para laboratório, onde procedeu-se a triagem dos tisanópteros. Foi obtido um total de 23 espécies de tripes, distribuídas em 15 gêneros e duas famílias. Nove destas espécies são novos registros para o Rio Grande do Sul ( $\left.{ }^{\star}\right)$ e outras duas para o Brasil ( $\left.{ }^{\star}\right)$. As espécies amostradas foram: Aneristothrips claripennis (Moulton, 1933) ${ }^{\star}$, Aurantothrips orchidearum (Bondar, 1931)*, Ceratothripoides lagoenacollus (Moulton, 1933) ${ }^{\star}$, Chaetanaphothrips orchidii (Moulton, 1907)*, Chaetisothrips striatus (Hood, 1935), Coremothrips pallidus Hood, 1925*, Craniothrips urichi Bagnall, 1915, Frankliniella bertelsi (De Santis, 1967), Frankliniella distinguenda Bagnall ${ }^{\star}, 1919$, Frankliniella gardeniae Moulton, 1948 Frankliniella gemina Bagnall, 1919, Frankliniella insularis (Franklin, 1908), Frankliniella oxyura Bagnall, 1919*, Frankliniella rodeos Moulton, 1933, Haplothrips fiebrigi Priesner, 1931, Hoodothrips lineatus (Hood, 1928), Microcephalothrips abdominalis (Crawford, 1910), Neohydatothrips denigratus (De Santis, 1966) Neohydatothrips fasciatus (Moulton, 1938) Neohydatothrips flavens (Moulton, 1941), Paraleucothrips minusculus Johansen, 1983 , Smicrothrips particula Hood, 1952, Thrips australis (Bagnall, 1915). PALAVRAS-CHAVE. Levantamento de espécies; tisanopterofauna neotropical; unidade de conservação.

The Thysanoptera comprises about 5,500 species commonly called thrips, distributed in two suborders: Terebrantia and Tubulifera, with eight and one families, respectively (Mound \& Marullo 1998, Mound 2002). According to Monteiro (2002), six of these families are represented in Brazil: Uzelothripidae, Merothripidae, Aeolothripidae, Heterothripidae and Thripidae belonging to Terebrantia and Phlaeothripidae to Tubulifera. The same author recorded 522 species grouped in 139 genera for

Revista Brasileira de Zoologia 23 (2): 367-374, junho 2006 
Brazil and listed about 35 thrips species from Rio Grande do Sul State (RS); for the neighbour state, Santa Catarina State, about 160 species were referred.

Recently, 83 thrips species were recorded inhabiting various plant species and litter at the Parque Estadual de Itapuã (RS) (PINENT et al. 2003). Of these, only 15 thrips species could be named, due to the lack of studies on this group. Such evidences indicate the vast specific richness of these insects in Rio Grande do Sul, and consequently the need of further surveys about them.

The present study lists the species of thrips sampled from the vegetation in Parque Estadual de Itapuã, together with information on the ecology and biology. Additional information on the species already recorded for PEI (PINENT et al. 2003) is also presented.

\section{MATERIAL AND METHODS}

Sampling was conducted in Parque Estadual de Itapuã (PEI), which is $60 \mathrm{~km}$ far from Porto Alegre city centre, between coordinates $50^{\circ} 50^{\prime}-51^{\circ} 05^{\prime} \mathrm{W}$ and $30^{\circ} 20^{\prime}-30^{\circ} 27^{\prime} \mathrm{S}$. In the regional context, PEI is the conservation unit showing the largest variety of environments, hosting diverse fauna and flora (Rio Grande do Sul 1997).

In different environments of PEI, shoots with and without flowers were sampled from June 2003 to April 2004. All the material was taken to the laboratory, where observation and sorting of thrips were done with the help of a stereomicroscope.

The specimens were kept in AGA preserving liquid (10 parts of ethanol $60 \%$, one part of glycerine and one part of glacial acetic acid) or in ethanol $60 \%$. To identify adults, a preparation for microscopy, as proposed by Mound \& MARullo (1996), was employed. The latter study was also basis for the identification of species, along with the works of DE SANTIS et al. (1980) and Moritz et al. (2001). The Thysanoptera reference collections of Departamento de Zoologia of UFRGS (Porto Alegre, Brazil) and of ESALQ (Piracicaba, Brazil) were consulted to confirm the identifications. Specimens studied are deposited in the collections cited above and also in the CSIRO Entomology collection (Canberra, Australia).

The species are presented alphabeticaly within the suborder, family and genus. All size measurements mentioned to the species refer to the females. A brief revision of the existing information is presented, with emphasis on the cases in which differences were found in comparison with the species descriptions. It is explicitly mentioned when only one sex was examined.

\section{RESULTS AND DISCUSSION}

\section{Terebrantia \\ Thripidae}

Aneristothrips claripennis (Moulton, 1933). Yellow colour; with exceptionally long mouth cone, extending up to the mesosternum. Sampled only on Achyrocline satureoides (Lamarck) De Candolle (Asteraceae). The larvae of this spe- cies have not been recorded yet. Females were found in both macropterous and brachypterous forms, whilst males were apterous or brachypterous. The description of this species done by Moulton (1933a) is poor in details, and according to Mound \& Marullo (1996), available slides are in bad conditions. Specimens sampled in the present study differ slightly from the description, for presenting larger size (1.2 $\mathrm{mm}$ ) and pronotal posteroangular setae smaller than those of the holotype. In the only record of this species for Brazil (Espírito Santo), it is also mentioned its association with $A$. satureoides (Silva et al. 1968). The other species of this genus, Aneristothrips rostratus De Santis, 1954, was recorded only to Argentina (Mound \& Marullo 1996).

Aurantothrips orchidearum (Bondar, 1931). Yellow with distinct dark spots on the median portion of the thoracic and abdominal tergites (Fig. 1). Few individuals were sampled on flowers of Epidendrum fulgens Brongniart (Orchidaceae). According to Mound \& Marullo (1996), this and the other species of the genus, Aurantothrips orchidaceus (Bagnall, 1909), are associated mainly to orchidaceans. Its presence was observed on many Orchidaceae in Bahia, Minas Gerais, Rio de Janeiro and São Paulo states, and also in Costa Rica (Silva et al. 1968, Mound \& Marullo 1996).

Ceratothripoides lagoenacollus (Moulton, 1933). Only females were examined. Specimens with brown tinge (Fig. 2). Pinent et al. $(2003,2005)$ also observed this thrips in PEI, referring to it as Ceratothripoides sp.1, with $93 \%$ of the individuals found on Stachytarpheta cayennensis (Richard) Vahl (Verbenaceae). Individuals sampled here differ slightly from those described by Moulton (1933b), originally based on specimens sampled on Casearia sylvestris Swartz (Flacourtiaceae) in Espírito Santo state. The specimens here examined have the lateral portion of the head with straight cheeks and, apparently, lack a pair of the pronotal posteromarginal minor setae. The number of setae in the anterior wing vein is also smaller (14-15). However, this was not an appropriate character, since it showed variation among individuals sampled. According to Mound \& Marullo (1996), a revision of this genus is necessary; five species are recorded to the Neotropical region. Only this species is recorded to Brazil (Monteiro 2002).

Chaetanaphothrips orchidii (Moulton, 1907). Yellow with hind wings having two distinct dark bands. Collected on Ficus luschnatiana (Miquel) Miquel (Moraceae). Originated from the Oriental Region, it is, however, widely distributed, especially in Central America, where it is known to cause damage to banana crops (Musa paradisiaca Linnaeus) (Mound \& Marullo 1996). In Brazil, its presence is cited for citrus in São Paulo (Monteiro et al. 1999). This genus includes about 20 species, of which three others are also known as harmful to various cultures (Mound \& KibBy 1998).

Chaetisothrips striatus (Hood, 1935). Approximately $1.7 \mathrm{~mm}$ long. With dark-brown colour; head and pronotum with strong reticulate striation. Only two individuals were ex- 


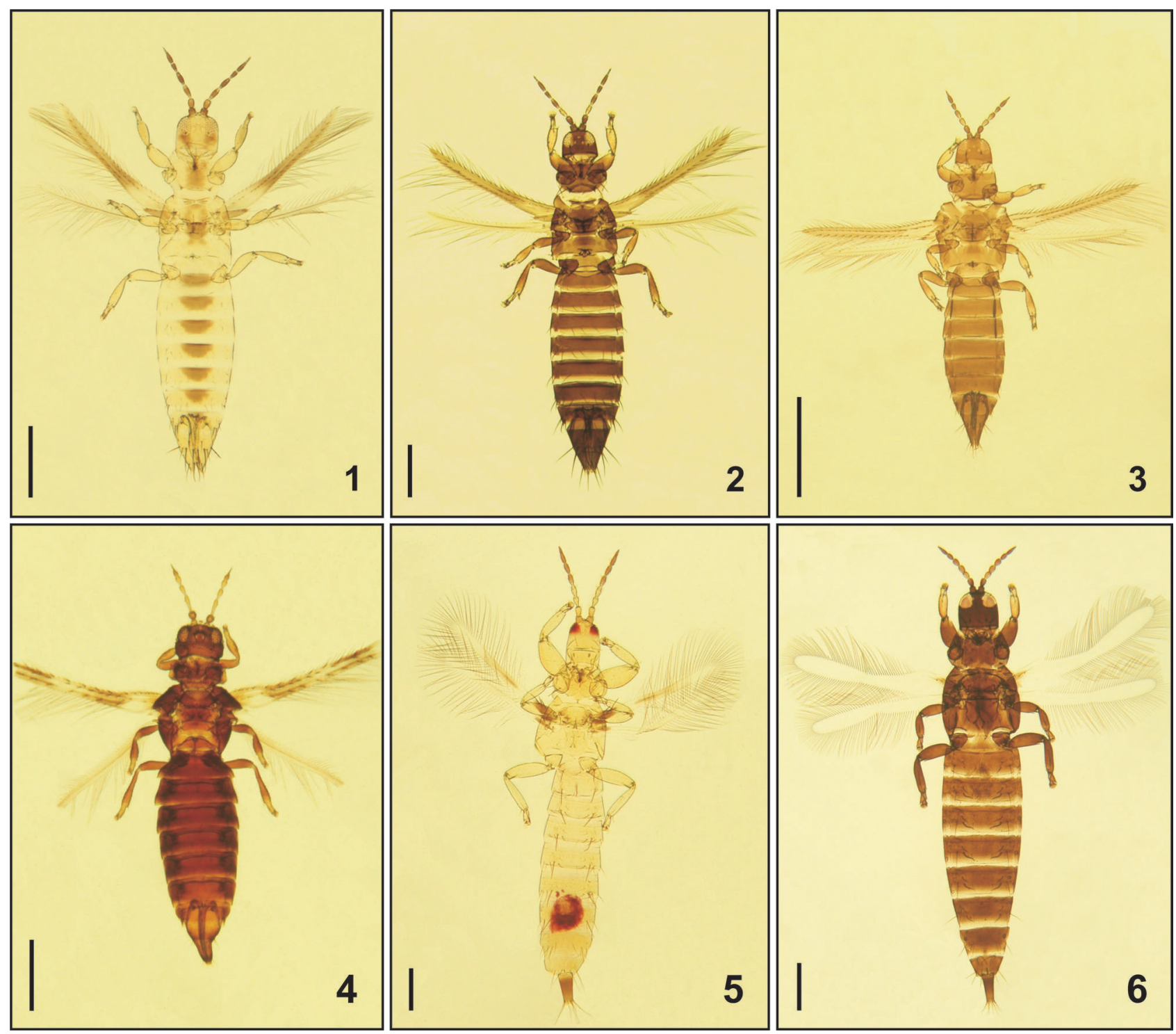

Figures 1-6. Some thrips species collected at Parque Estadual de Itapuã, Viamão, Rio Grande do Sul State, Brazil, from June 2003 to April 2004: (1) A. orchidearum; (2) C. lagoenacollus; (3) F. oxyura; (4) H. lineatus; (5) C. urichi; (6) H. fiebrigi. Scale bars $=300 \mu \mathrm{m}$.

amined. As in PINENT et al. (2003), this species was recorded on Chiococca alba (Linnaeus) Hitchcock (Rubiaceae). Mound $\&$ Marullo (1996) mention seven species to this genus, distributed mainly throughout Central America and Mexico. According to SiLva et al. (1968), this species was sampled in Rio de Janeiro and Rio Grande do Sul states.

Coremothrips pallidus Hood, 1925. Small $(1.1 \mathrm{~mm})$ and white coloured. With very narrow wings and setae with fringed apices. It was sampled on leaves of Asteraceae and Tiliaceae. Originally described from Panamá, it is found in many countries of Central America (Mound \& Marullo 1996). In Brazil it was recorded on leaves of Trema micrantha (Linnaeus) Blume (Ulmaceae) (Renata C. Monteiro, pers. comm.). PINENT et al. (2003) sampled from PEI an individual belonging to this genus inhabiting Homolepis glutinosa (Swartz) Zuloaga \& Soderstrom (Poaceae). The other species of this genus, Coremothrips nubilicus Hood, 1954, is also mentioned for Brazil (Santa Catarina), collected on Dalbergia sp. (Fabaceae). Frankliniella bertelsi (De Santis, 1967). Yellow colour. Compact antennal segments and very small interocellar III and pronotal setae. Many individuals were sampled from Asteraceae flowerheads. The species belongs to the minuta 
group, which comprises more than 25 species, all native to the Americas (Sakimura \& O’Neill 1979, Retana 1998a). Described from Brazil, it is recorded for Rio Grande do Sul and Santa Catarina, inhabiting various plant species. Recorded for PEI by PINENT et al. $(2003,2005)$ inhabiting seven plant species, especially asteraceans.

Frankliniella distinguenda Bagnall, 1919. Yellow; approximately $1.4 \mathrm{~mm}$ long. It also belongs to the minuta group. Sampled in abundance on Eupatorium inulifolium Humbolt, Bonpland \& Kunth (Asteraceae). It differs from F. bertelsi mainly by having interocellar III and pronotal setae slightly longer (Sakimura \& O'Neill 1979). It is also recorded from Argentina, Costa Rica and Paraguay (NAKAhara 1997). In Brazil it was observed on Myrtaceae, Asteraceae, citrus flowers (Rutaceae), among others (Silva et al. 1968).

Frankliniella gardeniae Moulton, 1948. Yellow coloured and 1.2 $\mathrm{mm}$ long. It differs in presenting a slightly expanded disc on the pedicel of the antennal segment III, and also small microtrichia in the anterior portion of the abdominal tergite IX. Only one individual was sampled, on Psidium guajava Linnaeus (Myrtaceae). It is distributed across various countries in Central America, very common on flowers (Mound \& MARUllo 1996). In Brazil it has been recorded only for São Paulo, inhabiting mainly gardenia flowers (Rubiaceae) and citrus, on which it has been reported damaging flower buds (Renata C. Monteiro, pers. comm.).

Frankliniella gemina Bagnall, 1919. Yellow colour. This species comprised about $10 \%$ of the total individuals sampled. It was found on 24 plant species, especially on shoots with flowers. It occurs in the southern (Paraná and Rio Grande do Sul) and southeastern (Rio de Janeiro and São Paulo) regions of Brazil, associated to various plants (SILVA et al. 1968). In Rio Grande do Sul, Bertels \& Ferreira (1973) recorded this thrips in American potato (Solanum tuberosum Linnaeus), oat (Avena sativa Linnaeus) and wheat (Triticum aestivum Linnaeus). It also occurs in Argentina, Chile, Paraguay and Peru (Nakahara 1997).

Frankliniella insularis (Franklin, 1908). Dark, with bicoloured anterior wings, with the basal portion distinctly light-coloured. Only three individuals were found, on three different plant species. OrTiz (1977) mentioned a high level of polyphagy to this species. It has a large geographical range across the American continent (Mound \& Marullo 1996). Popularly called the "orange tree thrips", it is cited to Brazil for the north-eastern, south-eastern and southern regions (Silva et al. 1968). In Rio Grande do Sul it was observed on Citrus aurantium Linnaeus (Rutaceae) (Bertels \& Baucke 1966). Pinent et al. $(2003,2005)$ recorded its presence in five plant species, all different from those recorded here for the same area (PEI).

Frankliniella oxyura Bagnall, 1919. Dark-brown colour; $1 \mathrm{~mm}$ of length (Fig. 3). Very small interocellar III. According to SAKIMURA \& O'Neill (1979), it is also included in the minuta group. Few individuals were sampled, mainly on flowers of
E. inulifolium. Recorded for the southern and south-eastern regions of Brazil, this, however, is the first record for Rio Grande do Sul. In Brazil, it has been collected from an array of plant species, especially from asteracean flowers (Renata C. Monteiro, pers. comm.). It is also found in Argentina and Paraguay (NAKAHARA 1997).

Frankliniella rodeos Moulton, 1933. Yellow colour. Very similar to F. gemina. One of the main differences is in the antennal segment II, which is entirely dark in F. gemina and lightcoloured in the basal half for $F$. rodeos. In this study, adults of this species presented high levels of polymorphism, both for size and colour. Most of the individuals sampled (42\%) belonged to this species. Found in 26 plant species, especially on shoots with flowers in Asteraceae. They were observed in the laboratory in many occasions feeding on petals, gynoeceum, androceum and also pollen grains of asteraceans. QuiNTANILLA (1980) mentions damage to citric fruits in Argentina. It is recorded for diverse plant species in the center-western, southern e south-eastern regions of Brazil (SiLva et al. 1968).

Hoodothrips lineatus (Hood, 1928). Dark coloured; $1.5 \mathrm{~mm}$ long (Fig. 4). Only one specimen was sampled from shoots with flowers of Lantana camara Linnaeus (Verbenaceae). Described from Trinidad, is recorded for Santa Catarina and Rio Grande do Sul states (Mound \& Marullo 1996, Pinent et al. 2003). This genus comprises three species, of which Hoodothrips constrictus (Hood, 1925) was also recorded for Brazil (SiLVA et al. 1968).

Microcephalothrips abdominalis (Crawford, 1910). Light-brown colour and approximately $1.3 \mathrm{~mm}$ long. Small head compared to the pronotum. Few individuals were recorded, inhabiting flowers of Asteraceae. It is considered an important pollinator agent for various asteraceans in India (ANATHAKRishnan et al. 1981a, b, Gopinathan et al. 1981). Popularly called the "composite thrips", it is widely distributed across the tropics, being the only species in the genus (DE SANTIs et al. 1980, Mound \& Marullo 1996). In Brazil its presence is recorded for Paraná, Rio Grande do Sul and São Paulo (Monteiro et al. 1996, Pinent et al. 2003).

Neohydatothrips denigratus (De Santis, 1966). Orange colour. Very frequent on Asteraceae, especially on Tagetes minuta Linnaeus Described from Argentina, it is recorded for the first time in Brazil. Many species of this genus were recorded for Brazil (Monteiro 2002). Monteiro et al. (1999) recorded one of them - Neohydatothrips samayunkur (Kudô, 1995) attacking leaves of Tagetes patula Linnaeus (Asteraceae) in São Paulo state.

Neohydatothrips fasciatus (Moulton, 1938). Yellow colour; forewings with three distinct dark bands. Sampled from shoots and flowers of E. inulifolium. It was not very common. Originally described from Brazil (Minas Gerais), inhabiting an unidentified Asteraceae. This is the first record for Rio Grande do Sul. 
Neohydatothrips flavens (Moulton, 1941). Light-brown; few individuals were sampled, inhabiting Asteraceae, Melastomataceae, Rubiaceae and Verbenaceae. This was the only species of the genus previously cited for Rio Grande do Sul (PINENT et al. 2003). Already recorded in Argentina (DE SANTIS et al. 1980), it was found by PINENT et al. (2003) in abundance in PEI, especially on Dodonaea viscosa Linnaeus (Sapindaceae) and Triumfetta abutiloides Saint-Hilaire (Tiliaceae).

Paraleucothrips minusculus Johansen, 1983. Whitish colour. Very frequent on Cordia verbenacea De Candolle (Boraginaceae) and L. camara commonly associated to leaves. The specimens examined differ from the description made by JOHANSEN (1983) for a female from Mexico. Females sampled in the present study are slightly larger $(1.1 \mathrm{~mm})$ and have a shorter mouth cone (not extending to the posterior margin of the pronotum), and longitudinal reticulations on the metanotum. Besides, no darker portion in the median region of the forewings was evidenced, as is informed in the description. Also recorded for Costa Rica by Mound \& MARullo (1996), this is the single species of the genus.

Thrips australis (Bagnall, 1915). Yellowish colour with dark markings on the abdominal tergites. Forewings with setal row on first vein nearly complete, without an interruption in the distal half (Monteiro et al. 2001). A few individuals were sampled on Myrtaceae and Verbenaceae. According to Mound \& Marullo (1996), this species is native from Australia and is now worldwide distributed, occurring on a variety of plants, especially myrtaceans. In Brazil it has been observed on Eucalyptus spp. (Myrtaceae) (Monteiro et al. 2001). Bertels \& Ferreira (1973) recorded this species in American potato (S. tuberosum), oat (A. sativa) and wheat (T. aestivum) in Rio Grande do Sul. This is the largest genus, comprising approximately 270 species, of which only four occur in Brazil (Monteiro 2002, Mound \& Zapater 2003).

\section{Tubulifera \\ Phlaeothripidae}

Craniothrips urichi Bagnall, 1915. Yellow, with the last abdominal segment dark (Fig. 5). Approximately $1.7 \mathrm{~mm}$ long. The presence of distinct dark bands on the forewings was also observed. Large number of individuals were found, associated to Leandra australis (Chamisso) Cogniaux (Melastomataceae), a host plant (PINENT et al. 2005). Macropteran and brachypteran females were observed. It has been recorded in some countries of Central America and Brazil, mainly on leaves. This is the only species of the genus (Mound \& Marullo 1996, Pinent et al. 2003).

Haplothrips fiebrigi Priesner, 1931. Dark colour and $2.3 \mathrm{~mm}$ long. (Fig. 6). It is uncommon, sampled mainly on flowers of Asteraceae and Rubiaceae. It is found in Argentina, Paraguay and Brazil (Mound \& Marullo 1996, Pinent et al. 2003). Along with Haplothrips gowdeyi (Franklin, 1908), it is the only species of this group recorded for Brazil (MonTEIRo
2002). This genus comprises about 230 species, many of them associated to asteracean flowers, especially in Europe (MOUnd \& ZAPATER 2003).

Smicrothrips particula Hood, 1952. Yellow coloured and $0.8 \mathrm{~mm}$ long (female). Laterally compressed body. Larvae and adults were sampled on L. camara and Verbesina subcordata De Candolle (Asteraceae). Adults and larvae are markedly agile, being able to move with ease among trichomes present on the leaves. In this study, macropterous and brachypterous adults were observed. PInENT et al. (2003) recorded this thrips as a predator of mites on Poaceae. However, it is possible that this is not the main feeding habit of the species, since they do not possess many of the characteristics of predator thrips mentioned by JoHANSEN \& MoJICA-GuzMán (1997). It differentiates from obligatory predator thrips, for example, because of its diminutive size, relatively short legs and gregarious habit. Described from Brazil (Santa Catarina), it was sampled in abundance by PINENT et al. (2003) on Asteraceae, Boraginaceae, Poaceae, Myrtaceae and Rubiaceae. This is the only species in the genus.

\section{FINAL CONSIDERATIONS}

Of the 23 species sampled in this study, nine are new record to Rio Grande do Sul - A. claripennis, A. orchidearum, C. lagoenacollus, C. orchidii, C. pallidus, F. distinguenda, F. gardeniae, F. oxyura and N. fasciatus - and two also more for Brazil - N. denigratus and $P$. minusculus. Nine other morphospecies were collected, but they could not be identified to specific level. They are placed in Frankliniella (2 spp.), Halmathrips (1 sp.), Heterothrips (3 spp.), Karnyothrips (1 sp.), Liothrips (1 sp.), Paraleucothrips (1 sp.). This last one is possibly an undescribed species (Laurence A. Mound, pers. comm.). According to the available literature, it is probable that all thrips recorded in this study have a primarily phytophagous habit. However, for most of the species presented here, information on the biology and ecology are scarce or inexistent in the literature.

Ten species recorded in this study were also sampled by Pinent et al. $(2003,2005)$ in PEI. Adding the data presented here to these previous results, 32 nominate species are associated to the vegetation of PEI. Approximately 40 other species are identified only to generic level. Adding the species recorded in the litter by PINENT et al. (in press), a total of 33 nominated species and about 65 identified to genus level or subfamily are enumerated for PEI.

The relatively high number of species not yet identified reflects the situation of the thysanopterofauna of this part of the country. The inexistence of recent identification keys for the thrips fauna of Brazil is one of the main difficulties faced by researchers. This situation is aggravated when working with an apparently unknown and undescribed fauna. The lack of extensive sampling across Brazilian territory completes the picture.

Members of the genus Frankliniella particularly constitute an extremely complex group to study, because of the large 
number of existing sinonimies. Many of these species vary in colouration along the adult phase and also in size, depending on temperature they were reared and also food source (RETANA $\&$ Mound 1994). The definition of the genus is turning wider and more diffuse, which makes the process of classification and recognition of the species difficult (RETANA 1998b). Only during the last eight years, about 40 species of the genus were described, most of them from Mexico (Johansen 1998a, b, 2000, 2002, Johansen \& Mojica-Guzmán 1998, 2003, Retana 1998a, Nakahara \& Monteiro 1999, Berzosa \& Maroto 2003, Lee \& Woo 2002, Mound et al. 2005). However, there are no identification keys including all these recently found species. Besides, the larger part of these descriptions is not accompanied by information on biological or ecological aspects, which limits the studies of such species both in natural and agricultural settings. Of the 10 most widely cited agricultural pest species (Mound \& Teulon 1995), only Frankliniella schultzei (Trybom, 1910) has been recorded for PEI by PINENT et al. (2005) though these authors referred to it as Frankliniella sp.8.

The genera Neohydatothrips and Heterothrips (Heterothripidae) are also worth of mention, having three species each. Members of Neohydatothrips comprise about 80 described species, of which 15 occur in Brazil (Mound \& Marullo 1996, Monteiro 2002). A large part of the species described from this country was based on a few specimens and scarce biological information.

Heterothrips comprises about 60 species, all original from the Americas. Monteiro (2002) records 13 species belonging to this genus for Brazil. Pinent et al. (2003, 2005) sampled three members of the genus from PEI, none of which was confirmed to species level. They all probably feed on flowers, and some present specificity towards host plants; nevertheless, little is known on the biology of this group (MOUND \& Marullo 1996, Mound \& Kibвy 1998). The three species of the genus cited in this study are possibly undescribed species (Laurence A. Mound, pers. comm.).

This reinforces the importance of conservation units in the maintenance and preservation of this fauna. Surveys of Thysanoptera and its biology, especially in natural environments for the Neotropics, are direly needed and urgent given the large gaps in our knowledge.

\section{ACKNOWLEDGEMENTS}

To Dr. Silvia M. Jesien Pinent for all the incentive, suggestions and also for pioneering the research with thrips in Rio Grande do Sul. To Biols. Alessandra Marins, Aline Quadros, Augusto Ferrari, Lucas A. Kaminski and M.Scs. Cristiano A. Iserhard, Eduardo C. Teixeira, Maria O. Marchiori and other members of the Laboratório de Ecologia de Insetos (UFRGS) for help in the field and lab. To Drs. Roberto Zucchi and Renata C. Monteiro for providing access to the Thysanoptera reference collections and the facilities of ESALQ. To Dr. Milton de Souza Mendonça Jr. for valuable suggestions to the manuscript.
To Dr. Roberto Johansen for the useful bibliographic material provided. To Dr. Laurence A. Mound for the identification of many thrips species and for the knowledge transmitted in our discussions. To CAPES for financial support and CNPq for the scholarships to the second and third authors.

\section{REFERENCES}

Anathakrishnan, T.N.; R. Varatharajan \& K. Gopinathan. 1981a. Seasonal periodicity of thrips infesting some Compositae in relation to pollination. Proceedings of the Indian National Science Academy, Calcutta, B47 (6): 811-815.

Anathakrishnan, T.N.; R. Varatharajan \& K. Gopinathan. 1981b. Pollination in Wedelia chinensis (Osbeck) Merr and Tridax procumbens L. (Compositae) by thrips (Thysanoptera: Insecta). Proceedings of the Indian National Science Academy, Calcutta, B47 (2): 159-165.

Bertels, A. \& O. Baucke. 1966. Segunda relação de pragas das plantas cultivadas no Rio Grande do Sul. Pesquisa Agropecuária Brasileira, Rio de Janeiro, 1: 17-46.

Bertels, A. \& E. Ferreira. 1973. Levantamento atualizado dos insetos que vivem nas culturas de campo no Rio Grande do Sul. Série Publicação Científica, Pelotas, 1: 1-17.

Berzosa, J. \& J. Maroto. 2003. New neotropical species of the genus Frankliniella Karny (Insecta: Thysanoptera: Thripidae). Studies on Neotropical Fauna and Environment, Lisse, 38 (2): 135-144.

De Santis, L.; A.E. Gallego de Sureda \& E.Z. Merlo. 1980. Estudio sinoptico de los tisanopteros argentinos. Obra del Centenario del Museo de La Plata, La Plata, 6: 91-166.

Gopinathan, K.; R. Varatharajan \& T.N. Ananthakrishnan. 1981. Incidence of Microcephalothrips abdominalis (Crawford) (Thysanoptera: Insecta) in relation to the pollination biology of the weed Ageratum conyzoides Linn. (Compositae). Proceedings of the Indian National Science Academy, Calcutta, B47 (4): 505-509.

Johansen, R.M. 1983. Nuevos thrips (Insecta: Thysanoptera; Terebrantia, Thripidae: Thripinae) de La Sierra Madre Oriental y del eje Volcanico Transversal, de Mexico. Anales del Instituto de Biología, Serie Zoología, México, 53 (1): 91132.

JoHANSEn, R.M. 1998a. The Frankliniella curiosa species group (Thysanoptera: Thripidae). Revista de Biologia Tropical, San Jose, 46 (3): 717-738.

JoHANSEN, R.M. 1998b. The Mexican Frankliniella desertileonidum Watson species assemblage, in the "intonsa group" (Insecta, Thysanoptera: Thripidae). Acta Zoologica Mexicana, México, 75: 143-161.

Johansen, R.M. 2000. The Mexican Frankliniella paracutinensis sp. nov. species assemblage, in the "intonsa group" (Insecta, Thysanoptera: Thripidae). Acta Zoologica Mexicana, México, 80: 1-49.

Johansen, R.M. 2002. The Mexican Frankliniella fusca (Hinds), F. pallida (Uzel) and F. schultzei (Trybom) species assemblages, 
in the "intonsa group" (Insecta, Thysanoptera: Thripidae). Acta Zoologica Mexicana, México, 85: 51-82.

Johansen, R.M. \& A. MojICA-GuZmán. 1997. Reconsideracion del concepto depredador y parasitoide en tisanopteros Mexicanos (Insecta) de interes en control biologico natural. Folia Entomologica Mexicana, México, 97: 21-38.

Johansen, R.M. \& A. Mojica-Guzmán. 1998. The Mexican Frankliniella anitahoffmannae sp. nov. species assemblage, in the "intonsa group" (Insecta, Thysanoptera: Thripidae). Acta Zoologica Mexicana, México, 75: 1-16.

Johansen, R.M. \& A. Mojica-Guzmán. 2003. The Mexican Frankliniella aurea Moulton, F. bisaetaevenusta sp., nov. and F. prothoraciglabra sp. nov. species assemblages, in the "intonsa group" (Insecta, Thysanoptera: Thripidae). Acta Zoologica Mexicana, México, 89: 201-240.

LeE, G.S. \& K.S. Woo. 2002. A new Frankliniella species (Thysanoptera, Thripidae) on Gramineae from Korea. Insecta Koreana, Seoul, 19 (2): 199-204.

Monteiro, R.C. 2002. The Thysanoptera fauna of Brazil, p. 325340. In: R. Marullo \& L.A. Mound (Eds). Thrips and Tospoviruses: Proceedings of the $7^{\text {th }}$ International Symposium on Thysanoptera. Canberra, Australian National Insect Collection, XII+379p.

Monteiro, R.C.; L.A. Mound \& R.A. Zucchi. 1996. Thrips species from three counties of the state of São Paulo. Anais da Sociedade Entomológica do Brasil, Londrina, 25 (2): 351 353.

Monteiro, R.C.; L.A. Mound \& R.A. Zucchi. 1999. Thrips (Thysanoptera) as pests of plant production in Brazil. Revista Brasileira de Entomologia, São Paulo, 43 (3/4): 163171.

Monteiro, R.C.; L.A. Mound \& R.A. Zucchi. 2001. Espécies de Thrips (Thysanoptera: Thripidae) no Brasil. Neotropical Entomology, Londrina, 1: 61-63.

Monteiro, R.C.; M.A.C. Zawadneak \& L.A. Mound. 1999. Neoydatothrips samayunkur (Kudô) (Thysanoptera: Thripidae) infesting marigold (Tagetes patula, Compositae) in Brazil. Anais da Sociedade Entomológica do Brasil, Londrina, 28 (2): 323-326.

Moritz, G.; D.C. Morris \& L.A. Mound. 2001. ThripsID - Pest thrips of the world. An interactive identification and information system. Canberra, CD-Rom published by ACIAR.

Moulton, D. 1933a. The Thysanoptera of South America III. Revista de Entomologia, Rio de Janeiro, 3 (2): 227-262.

Moulton, D. 1933b. The Thysanoptera of South America II. Revista de Entomologia, Rio de Janeiro, 3 (1): 96-133.

Mound, L.A. 2002. Thysanoptera biodiversity in the Neotropics. Revista de Biologia Tropical, San Jose, 50 (2): 477-484.

Mound, L.A. \& D.A.J. Teulon. 1995. Thysanoptera as phytophagous opportunists, p. 3-19. In: B.L. PARKER, M. SKINNER \& T. LEwIs (Eds.). Thrips Biology and Management. New York, Plenum Press, XVI+636p.
Mound, L.A. \& G. Kiвby. 1998. Thysanoptera - An identification guide. Wallingford, CAB International, VI+70p.

Mound, L.A. \& M.C. Zapater. 2003. South American Haplothrips species (Thysanoptera: Phlaeothripidae), with a new species of biological control interest to Australia against weedy Heliotropium amplexicaule (Boraginaceae). Neotropical Entomology, Londrina, 32 (3): 437-442.

Mound, L.A. \& R. Marullo. 1996. The thrips of Central and South America: an introduction (Insecta: Thysanoptera). Memoirs on Entomology, International, Gainesville, 6: 1488.

Mound, L.A. \& R. Marullo. 1998. Two new basal-clade Thysanoptera from California with Old World affinities. Journal of the New York Entomological Society, New York, 106 (2-3): 81-94.

Mound, L.A.; S. NAKahara \& M.D. Day. 2005. Frankliniella lantanae sp. nov. (Thysanoptera: Thripidae) a polymorphic alien thrips damaging Lantana leaves in Australia. Australian Journal of Entomology, Canberra, 44 (3): 279-283.

NAKAHARA, S. 1997. Annotated list of the Frankliniella species of the World (Thysanoptera: Thripidae). Contributions on Entomology, International, Gainesville, 2 (4): 355-389.

NAKAHARA, S. \& R.C. Monteiro. 1999. Frankliniella zucchini (Thysanoptera: Thripidae), a new species and vector of tospovirus in Brazil. Proceedings of the Entomological Society of Washington, Washington D.C., 101 (2): 290-294.

OrTIZ, M.P. 1977. El genero Frankliniella Karny (Thysanoptera: Thripidae) en el Peru. Revista Peruana de Entomologia, Lima, 20: 49-62.

Pinent, S.M.J.; H.P. Romanowski; L.R. Redaeldi \& L.A. Mound. 2003. Thrips species (Thysanoptera) collected at Parque Estadual de Itapuã, Viamão, RS, Brazil. Neotropical Entomology, Londrina, 32 (4): 619-623.

Pinent, S.M.J.; H.P. Romanowski; L.R. Redaelli \& A. Cavalleri. 2005. Thysanoptera: plantas visitadas e hospedeiras no Parque Estadual de Itapuã, Viamão, RS, Brasil. Iheringia, Série Zoologia, Porto Alegre, 95 (1): 9-16.

Pinent, S.M.J.; H.P. Romanowski; L.R. Redaelli \& A. Cavalleri. (in press). Species composition and structure of Thysanoptera communities in different microhabitats at Parque Estadual de Itapuã, Viamão, RS. Brazilian Journal of Biology, São Carlos.

QUintanilla R.H. 1980. Trips, características morfológicas y biológicas. Especies de mayor importancia agrícola. Buenos Aires, Ed. Hemisferio Sur, 60p.

Retana, A.P. 1998a. Reestablecimiento de los géneros Frankliniella, Exophtalmothrips y Bolbothrips (Thysanoptera: Thripidae). Revista de Biologia Tropical, San Jose, 46 (2): 385-396.

Retana, A.P. 1998b. Una visión filogenética de Frankliniella (Thysanoptera: Thripidae). Revista de Biologia Tropical, San Jose, 46 (2): 397-406.

RetanA, A.P. \& L.A. Mound. 1994. Thrips of the Frankliniella minuta group (Insecta: Thysanoptera) in Costa Rican

Revista Brasileira de Zoologia 23 (2): 367-374, junho 2006 
Asteraceae flowers. Revista de Biologia Tropical, San Jose, 42: 639-648.

Rio Grande do Sul. 1997. Plano de Manejo Parque Estadual de Itapuã. Porto Alegre, Secretaria da Agricultura e Abastecimento, Departamento de Recursos Naturais Renováveis, 158p.

SAKImURA, K. \& K. O’Neill. 1979. Frankliniella, redefinition of genus and revision of minuta group species (Thysanoptera: Thripidae). Technical Bulletin/United States Department of Agriculture, Washington, 1572: 1-49.

Silva, A.G.A.; C.R. Gonçalves; D.M. Galvão; A.J.L. Gonçalves; J. Gomes; M.M. Silva \& L. Simoni. 1968. Quarto catálogo dos insetos que vivem nas plantas do Brasil, seus parasitos e predadores. Parte II $-1^{\circ}$ Tomo - Insetos, hospedeiros e inimigos naturais. Guanabara, Ministério da Agricultura, Departamento de Defesa e Inspeção Agropecuária, XXVIII+622p.

Received in 24.VI.2005; accepted in 15.IV.2006. 